\title{
The Nature of Waqf Land in Its Implementation Practices in Gorontalo Province
}

\author{
Syamsuddin Pasamai*, Nurul Qamar*, Abdul Qahar*, Misnawaty S. Nuna** \\ *Lecturer at post-sustainability Program of Muslim University of Indonesia \\ ** Student of Doctoral Program of Law Sciences of Muslim University of Indonesia and Civil Servant at the \\ Regional Office of Religious Affair Ministry of Gorontalo Province, Indonesia \\ Corresponding Author: Syamsuddin Pasamai
}

\begin{abstract}
Waqf as a worship to God and also as a socially function. In its function as a worship, waqf is expected to be a provision for the life in the afterlife. While in the other function, waqf is a very valuable asset in development. This research is to analyze the nature of land representation in its practice implementation in Gorontalo Province. The research method used in this study is normative research method and empirical research. The result of this research shows that the nature of the land endowments is to get closer to Allah SWT, which contains the meanings of charitable deeds continuously and useful to the whole society. However, in its implementation practice, the land waqf in Gorontalo is less effective caused by the waqf land mostly do not have the Deed of Waqf Pledge, so it is difficult to be registered at the National Land Agency for getting the certification. The substance of the land waqf feels hard to make the effective practice of the land recipients because there are still so many waqf land that has not been certified.
\end{abstract}

Keywords: Practice, Implementation, Land, Waqf, Gorontalo

\section{PREFACE}

Land is one of the agrarian resources that have an important role in life and human life. ${ }^{1}$ One of the problems in the archipelago is the representation of the land. This is because waqf is a religious institution that can be used as one of the means for the development of religious life, especially for the religion of Islam in order to achieve the spiritual and material welfare to a just and prosperous society based on Pancasila.

According to the results of the writer's research, the practice of the land endowment in Gorontalo has not been well implemented because of the many influenced factors such as the arrangement of Waqf land, the implementation is also not good because the managers have not understood the Waqf management, so that many waqf lands are not well managed. Therefore, the writer will discuss some matters relating to the nature of the land waqf which namely the arrangement of the land endowment or land waqf.

The waqf institution known in the teaching of Islam has often been done in Indonesia especially those who are Muslims long before the independence. This is not strange because the land in Indonesia used to stand many Islamic kingdoms. Although it is an institution derived from the teaching of Islam, but as if it is an agreement between the jurists that the waqf institution is a problem in the customary law of Indonesia, because the acceptance of this waqf institution comes from a habit in the association of life, therefore, it is not uncommon for the people to build the mosques or Pesantren for mutual interest in mutual cooperation. ${ }^{2}$ Moreover, waqf legal institutions originally from the Islamic law can be considered pervaded into a customary law as set forth in Supreme Court Decision Number 163/K/Sip/1963. ${ }^{3}$

Because of the importance of land acquisition problems in Gorontalo Province, it is necessary to regulate further in the form of government regulations or regional regulations. It has been affirmed in Article 49 Paragraph (3) of UUPA, so that its realization was born the Government Regulation Number 28 Year 1977 about the Owned Land Representation approved by the President on May 17, 1977 as published in the State

1 Hardianto Djanggih dan Salle. Aspek Hukum Pengadaan Tanah bagi Pelaksanaan Pembangunan untuk Kepentingan Umum. Pandecta: Research Law Journal, Volume 12, Nomor 2, 2017.hlm.166

2 Saroso dan Nico Ngani, 1984, Tinjauan Yuridis Tentang Perwakafan Tanah Milik, Liberty, Yogyakarta, hal. 18

3 Chidir Ali, 1979, Yurispondensi Indonesia Tentang Hukum Agraria Jilid 1, Binacipta, Bandung hal 263-267 
Gazette of Republic Indonesia Year 1977 Number 38 and Elucidation of the Government Regulation Number 28 Year 1977 as contained in Supplement to the Number 3107 Gazette.

During the long period of time, the existence of the government regulations has been perceived as urgent, because the facts show that the land regeneration has long been going on but it has not been implemented well even though its laws and regulations have been in place. This is because it has not met the need for ways of waqf, also open the desire of the emergence of things that are not desirable caused by the absence of the real and the complete data on the waqf land. Sometimes it need the explanation of the nature and the purpose of waqf itself, mainly due to the existence of various form of waqf such as family waqf, general waqf, etc. and the absence of the necessity to register the objects which are represented, so that that waqf objects no longer become the property of the heirs of the board (nadzir).

Such incidents can cause the unrest among Muslims and lead to antipathy. On the other hand, many disputes over land are caused by the unclear status of the land so that if not immediately arranged, it will not only reduce the religious awareness of those who embrace Islam, but even farther will hamper the efforts of the government to promote the enthusiasm and the guidance of the religious obligations as contained in the teachings of Pancasila and furthermore in the outline of the People"s Consultative Assembly Decree Number IV/MPR/1973 on the Guidelines of State Policy. With the issuance of Government Regulation No 28 of 1977 and the various regulations of its implementation at that time, there has been a renewal in the fields of land representation, where the question of the waqf land belonging to it, has been regulated, disciplined and directed in such a way that it truly fulfills the nature and the purpose of the representation accordance with the teachings of Islam.

Furthermore, it is hoped that with the various regulations, the questions of waqf land is placed in the actual proportion. ${ }^{4}$ In addition, with the birth of the Government Regulation Number 28 of 1977 is a waqf institution which is a religious institutions of Islam then entered into customary law, has now been formalized in the national land law system into an institution of aggregation, subsequently leading as the embryo of the national waqf institution in government regulation number 28 year 1977. This is a concrete step in the framework of realizing the establishment of the national legal system.

\section{DISCUSSION}

\section{A. Waqf Land Arrangement}

The government regulation number 28 of 1977 is regulated only social waqf which is for the public land owned. The other forms of the endowment or waqf such as family waqf is not included as stated in government Regulation number 28 year 1977. Such restriction are necessary to avoid the obscurity of waqf issues. Similarly, the objects is limited to the land only. It is also meant to avoid the chaos in the future.

The government regulation no. 28 of 1977 formulates that waqf is a legal act of a person or legal entity that separates a portion of his property in the forms of land property and institutionalize it for all time for the interest of worship or other public interest in accordance with the teaching of Islam. The separation of property portion in the form of property belongs serves to perpetuate the waqf objects that have been set aside in accordance with the purpose of waqf. It is affirmed in Article 2 of the government regulation number 28 year 1977 the function of waqf is to perpetuate the benefits of waqf objects in accordance with the purpose of waqf.

With the respect to the nature of eternity and immortality of the waqf land, then, beside the waqf land must be a property rights, it is also must be for the benefits of the people which much greater and can be enjoyed by the community, the waqf land also have the accordance with the purpose of the social function ${ }^{5}$ of the land rights adopted by UUPA. As for the problem of land representation or land waqf whose status and designated is used as personal or family interest (Expert waqf) is not included in the scope and extent of the arrangement.

This kind of scope is required with the intent and purpose of avoiding and blurring in the matter of waqf. In the case of a person who endows his land for the benefits of a personal or family (waqf expert), so in order not to complicate later after the person receiving the waqf or Nadzir dies, given that waqf cannot be transferred, either by way of grant, sale and purchase, inheritance and others, then the waqf should be considered as a grant.

To the above description, then the scope of the arrangement of waqf land covers: ${ }^{6}$

1. The repossessed land or waqf land is land of the ownership because it has the strongest and most fulfilling character of the landowner, so from that nature, the landowner is not tied to the time and certain requirements with the use ownership. Therefore, if the land is reproduced or be for waqf, it does not cause any consequences that can disturb the nature of the land waqf institution.

4 Abdurahman, 1984, Masalah Perwakafan Tanah Milik dan Kedudukan Tanah Wakaf di Negara Kita, Alumni, Bandung hal 3

5 Muhsin, 2004, Ikhtisar Sejarah Hukum, STIH IBLAM, Jakarta, hal 74

6 Taufik Hamami, 2003, Perwakafan Tanah dalam Politik Hukum Agraria, Tata Nusa, Jakarta, hal 87-88

DOI: $10.9790 / 0837-2303098190 \quad$ www.iosrjournals.org $\quad 82$ |Page


2. The waqf land should be reserved for the public, not for the personal gain, because it will bring the benefits to the community. This provision is attached to the land rights held in UUPA.

3. The land of waqf is instituted for the eternity. No time-honored waqf.

4. The purpose designated as the interest of worship or public interest.

5. Waqf terminates the ownership relationship between waqif with mauqufbih and the subsequent ownership status belongs to the public.

6. Waqif cannot draw back to the land that has been represented.

7. The pledge must be made in the presence of the pledge officer deed of waqf, in order to obtain an authentic deed which will be used in various respects such as to register the land head of the office of the National land agency or a dispute that occurred in the future.

Based on the above description, the institutional waqf treasures are preserved and the purpose can be accomplished, here is the important role of Nadziras the party entrusted or given the mandate to manage and maintain the treasures of waqf. Nadzir is not only responsible for maintaining it, but also representing the wadf property management inside and outside of the law, such as the periodic report to KUA officials, ${ }^{7}$ defending it when prosecuted in the court. ${ }^{8}$ In the practice of community life, a plot of land which has been reproduced will have a special status which namely the isolation of waqf land for transaction (buying and selling, keasing, grant, inheritance, guarantees and other forms of rights transfer). ${ }^{986}$ As a result, it also seems to be categorized as a rechtpersoon (legal entity) that is a legal person who has the rights and obligations in the life of the law a legal subject. It is said that, because from the ordinance to the administrators, all activities in the community is an activity of waqf's own property whose implementation is represented by Nadzir.

In order to obtain the legal force over the land represented, a waqf pledge must be made by a deed by the head of KUA as the officer of the pledge deed. The implementation of the pledge of endowment, as well as the certificate of endowment certificates are considered valid, if attended and witnessed accompanied by proof of the land ownership. ${ }^{1087}$ after the pledge deed of waqf is made, the subsequent registration of the land endowment to the land office of the regency/city to obtain ${ }^{1188}$ a certificate. Waqf land certificate is a national program as the responsibility of government and society. Therefore, to know for sure the amount of waqf land in all of Indonesia, it should be held the data collection completely.

There are still so many people who do the land endowments without a pledge of waqf and are not registered. Based on the results of the study that approximately 1,081 locations with a land area of 2,096,954.19 $\mathrm{m}^{2}$ have not been registered in the office of the National Land Agency of Gorontalo and the land does not have a certificate. This is due to: First, the legal culture of the citizenry survives on the customary tradition and religious customs; Second, the implementation of the law; Third, the legal communication, education and knowledge of village officers; Fourth, the waqif attitude to the land representation done simply.

The above description illustrates that there are a lot of waqf lands that have not been registered at the National Land Agency Office in Gorontalo because of the many obstacles encountered in Waqf land titling due to the cost issues. Whereas the minister of home Affairs has issued the Decree No 348/1982 on the Land Certification for Religious Law Institutions, Social Legal Entities, and Educational Institutions which become the object of prona in which one of his dictum stated that "in carrying out the massive land certificates, the lands controlled/ possessed by Religious Law, Social Law and Educational Institutions use directly for the religious, social and educational purposes maybe the object of the National Agrarian Project (Prona). However, until now the waqf managers do not use it so the most of waqf land in Gorontalo has not been registered yet. It can be seen in the following table:

Table 1. Number of Unregulated Land of Waqf at National Land Agency Office in Gorontalo

\begin{tabular}{|l|l|l|}
\hline Region/City & Number of Locations & Surface Area in $\mathbf{~ m}^{\mathbf{2}}$ \\
\hline Gorontalo City & 110 & $73.716,11$ \\
\hline Gorontalo Region & 339 & $1.199 .536,60$ \\
\hline Bonebolango Region & 4 & $1.995,61$ \\
\hline Boalemo Region & 258 & $204.441,12$ \\
\hline Pohuwatu Region & 246 & $430.267,50$ \\
\hline North Gorontalo Region & 124 & $186.994,25$ \\
\hline Total & $\mathbf{1 0 8 1}$ & $\mathbf{2 . 0 9 6 . 9 5 4 , 1 9}$ \\
\hline
\end{tabular}

Data Source: Ministry of Religious Affairs of Gorontalo Province, 2017.

\footnotetext{
Pasal 6 dan \& Peraturan Pemerintah Nomor 28 Tahun 1977

Pasal 17 Peraturan Menteri Agama Nomor 1 Tahun 1978

Ter Haar, 2001, Asas-asas dan Susunan Hukum Adat, Penebar Swadaya, Jakarta, hal 136

10 Op cit Pasal 9 Peraturan Pemerintah Nomor 28 Tahun 1977

11 Pasal 10 Peraturan Pemerintah Nomor 28 Tahun 1977
}

DOI: 10.9790/0837-2303098190 www.iosrjournals.org 
Based on the above data, the land waqf in the implementation practice in Gorontalo province has not been implemented properly, so it needs to be coordinated well between the Ministry of Religious Affairs with the local National Land Office (PBN) so that all existing waqf land can be registered with the National Land Office and have a strong legal base and have a legal certainty. Because if not registered at the BPN office then it could be a dispute in the future. To prevent this, so the waqf land does not fall into unauthorized hands, it is necessary to do the following safeguards:

1. Immediately provide a certificate of waqf land in order to have the power of law. Technically, the grant of waqf land certificate dose require the sincerity of nadzir waqf because the cost is not small, so that the role of interested parties to the existence of waqf land, especially the role of National Land Agency and Local Government in order to facilitate its management. The role of National Land Agency is very necessary in an affect to facilitate the process of making the land certificate. The role of local government in the framework of regional autonomy is needed in the framework of its financing.

2. Provide the announcement of the uncertified land so that the local community in particular is encouraged to provide assistance in land certification.

3. Give full advocacy or legally problematic from nadzir, waqf, government, legal aid agencies or legal expert on waqf property whicj is a treasure of society. This is must be done in an integrated manner in order to obtain the maximum result.

4. The utilization and empowerment of waqf land productively. The utilization of land and waqf land empowerment that should be prioritized is a waqf land that has the great economic potential. This security measure should involve all interested parties, such as nadzir, waqf, government, Islamic economic institutions and general public.

5. Immediately enacted the law on Land Pwnership which in it also regulates its own chapters fully and intact on the land's representation. This law is important regarding the protection and the utilization of waqf land.

Another problem that often occurs in the community is the Government Regulation Number 28 Year 1977 concerning the land endowment which has long prevailed compared with the development of real needs or the necessities of life Muslims which often experience a clash in practice, because the scope is felt too narrow. For example, the land that should be represented must be the property rights not the right to build (HGB). Whereas in practice, there is often a status of HGB. If the land to which HGB is to be represented, it must first be changed to a new property right represented. This seems to be quite inconvenient to the donor.

Not a few of the land that has been represented has been charged. Often there is a decade-long and dead waqif declaration of land, his heirs are demanding the land and denying any unlawful representation and filing lots of proof of property rights to the land. In this case, the Article 50 of Law Number 7 of 1989 on Religious court and as amended by Law Number 3 Year 2006 has given its limitations concerning the right of property civility is not the authority of the religious court but the General court. That is, if a dispute arose in waqf land ownership, it must be decided by civil verdict. The Religious court can only adjudicate the process of representation; whether or not there is an act of condoning the land not on the status of the land. ${ }^{89}$

\section{B. Waqf Land Ownership Registration}

One of the things that has never been implemented carefully is the registration of lands that are represented in accordance with the provisions of UUPA. Waqf land registration is very important, both in terms of legal order and in terms of land administration and the use of land in accordance with the legislation of the agrarian law.

The obligation to register the land endowments is regulated in Article 10 of the government regulation number 28 of 1977 which is further elaborated in the regulation of the minister of Home Affairs No 6 of 1977 on the Produce of Land Registration on the Ownership of the Land ownership.

After the Pledge Deed of Waqf is executed, the deed officer of waqf pledge on behalf of the concerned nadzir is required to apply to the regent/mayor c.q The Office of the National Land Agency to register the ownership of the land according to the provisions in Government Regulation Number 24 of 1997 concerning the land registration. The applicant of the land registration shall be submitted not later than 3 months after the pledge deed of waqf.

For the purpose of registering the land of property rights, to the Land office must be submitted:

a) Letter of application for consent/affirmation of his right to the land

b) The letters of the land ownership and other required information in connection with the request for the conversation and registration of the land rights.

c) The pledge deed of waqf made by the official of deed of pledge deed

d) The letter of approval from the local religious affairs office concerning the concerned nadzir.

After receiving the request for the land grant registration, the head of the local land agency office record the ownership of the land belonging to the land and certificate book. According to the provision of Article 7 paragraph (2) of the Regulation of the Minister of Home Affairs Number 6 of 1977, to the land owned 
by the represented before being registered at the National Land Agency Office of the regency/city, the intended recording shall be made after the land has been made its certificate.

After the registration of the land ownership is recorded in the land book and certificate, then the concerned nadzir must report to the official appointed by the minister if religious affairs. If nadzir consist of groups of the people, then those written in the land books and in the certificate are the names of the people of the group accompanied by their positions in the stewardship. Whereas if nadzir is a legal entity, it is written in the book of land and in certificate by the name of the legal entity.

The provisions in Article 10 of the Regulation of the Minister of Home Affairs Number 6 year 1977, in the case of nadzir which consist of groups of people and should be deleted if there are some who is resigned or died. Recording of the replacement of a new nadzir names on the land book and certificate after a letter of the approval from the office of the religious affairs of the sub district on the replacement of the nadzir. The replacement of the nadzir's names did not result in the transition from the land concerned.

What about the waqf land in Gorontalo before the Government Regulation Number 28 Year 1977 on such waqf land? Therefore, the registration must be done as stipulated in Article 15 and Article 16 of the Regulation of the Religious Affairs Minister no. 1 of 1978 that the registration is done by the respective administrators (Nadzir) to the office of the Religious Affairs of sub district,if the nadzir concerned no longer exists, his registration to the office of the sub district Religious Affairs shall be conducted by the waqif or his heirs, the offspring of nadzir or community members who know it; and the registration shall be enclosed or accompanied by the following letters:

a) An explanation of the land or certificate of the village head concerning the representation of the land

b) Two people who witnessed the pledge of waqf or istifadhah witnesses (who knew or heard about the representation)

Furthermore, the officer of pledge deed of waqf shall stipulate the pledge of waqf substitute pledge to prove that the registration of waqf land that occurred before the issuance of government regulation number 28 year 1977. Thus, it has been registered and recorded that waqf at the office of the National Land Agency in making a certificate of the property rights which are represented, the waqf land already has a strong evidence of waqf certificate.

Waqf land certificate is a national program as the responsibility of the government and society. Therefore, to know exactly the amount of waqf land in Gorontalo must be for sure registration. There are still many people who do the land endowments without a pledge of waqf and are not registered. It can be seen in table one above. Thus. To compare the waqf land that has been registered and already have a certificate, can be seen in the following table:

Table 2. Number of Location and the Total land Area of Certified Waqf in Gorontalo Province

\begin{tabular}{|l|l|l|}
\hline Region/City & Number of Locations & Surface Area in $\mathbf{~}^{\mathbf{2}}$ \\
\hline Gorontalo City & 168 & $648.555,00$ \\
\hline Gorontalo Region & 358 & $507.484,00$ \\
\hline Bonebolango Region & 250 & $202.035,45$ \\
\hline Boalemo Region & 49 & $52.034,00$ \\
\hline Pohuwatu Region & 17 & $18.495,00$ \\
\hline North Gorontalo Region & 65 & $66.120,00$ \\
\hline Total & $\mathbf{9 0 7}$ & $\mathbf{1 . 4 9 4 . 7 2 3 , 4 5}$ \\
\hline
\end{tabular}

Data Source: Ministry of Religious Affairs of Gorontalo Province, 2017.

Based on the above table, the number of waqf land which has been registered and has a certificate of 907 locations with a total land area of $1,494,723.45 \mathrm{~m}^{2}$, when compared with those who have not registered and do not have a certificate, so it can be concluded that the practice of the land representation or land waqf in Gorontalo Province has not been realized optimally.

Before the enactment of Law No. 28 of 1977, the changes in the status of the represented law can be done by the managers (nadzir) without a convincing a reason. This such a thing that would certainly generate a reaction in society, especially from those who are directly concerned to the land represented. Therefore, in the Government Regulation No. 28 of 1977 there are the restrictions and in addition the purpose of a status change must first obtain a permission from the Minister of Religious Affairs or the Head of the Provincial Ministry of Religious Affairs or its appointed officials. Given such limitations, it is hoped that the avoidable practices may be harmful to the representation. For the purpose of the land administration, the changes in status of waqf are required to be registered with the component authority.

According to the Provision of Article 11 paragraph (1) of the Government Regulation No. 28 of 1977, basically on the land of property that has been reproduced cannot be made the changes of designated or the other use than those referred to in Waqf pledge. In this case, it does not mean that it also cannot be made the changes 
to the representation of the land owned. However, in Article 11 paragraph (2) determined that the deviation from the provisions referred to in paragraph (1) may only be applied to the certain matters after the prior written approval of the minister of Religious is no longer in accordance with the purpose of waqf as waqif, and because of the public interest.

In order to change the status of waqf land use, nadzir is obliged to apply to the Head of the Ministry of Religious Affairs c.q. Head of the Islamic Affairs through the Head of the Office of Religious Affairs and Head of the division of Islamic Affairs which authorized to give the writing approval or rejection on the request changes in the use of waqf land.

In the event of alteration of the repossessed land status and the change in its use as a result of a deviation as it is done in certain cases then the nadzir (manager) is obliged to report it to the regent/mayor c.q. the Head of the Regency/Municipal Land Office to obtain the further settlement.

\section{The Settlement of Waqf law}

The conflict is a situation or condition of the contradiction existence or non-conformity between the parties who will and are in a relationships or cooperation. In general, the conflicts will occur anywhere as long as there is an interaction between the relationships and between the fellow human beings, either between the individuals and individuals or groups with groups in doing things. According to Rachmadi Usman, ${ }^{1298}$ the word conflict and dispute both contain an understanding of the existence of the different interests between two or more parties, but both can be distinguished. A conflict, a situation where two or more parties are faced with a difference of interest, will not develop into a dispute if the party who feels the aggrieved simply harbored a feeling of dissatisfaction or concern. A conflict turns into a dispute whenever the disadvantaged party has expressed his dissatisfaction or concern, either directly to the parties deemed to be cause of the loss or to the other party. Thus, a dispute is a continuation of a conflict or a conflict will turn into a dispute if it cannot resolved. ${ }^{13}$

In the law of Anthropology Science, Ihromi provides several alternative dispute solutions in which many societies use them: ${ }^{14}$

a) Leaving it (Lumping it). The persons who feel unfair treatment take the decision to ignore the issue that raises its demands and continue its relationship with the party that feels disadvantageous.

b) Ducking (avoidance). The parties who feel they are choosing to reduce the relationship with those who harm them or completely stop the relationship.

c) Coercion, one party imposes a unilateral solution on the other.

d) Negotiation, the two opposing parties are the decision makers. The solution of the problem faced by both parties without any third party interferes.

e) Mediation, the existence of a third party that helps the two disputing parties to find an agreement.

f) Arbitration, the dispute party whose decision is approved by the parties to the dispute

g) Adjudication, the settlement by a third party who has the authority to intervene in the decision and to exercise without regard to the consent of the parties concerned.

Concerning to the land dispute of waqf, it can be defined that the dispute is a process of the interaction between two or more persons or groups which fighting for their interests of the same object such as the land and other objects related to the land (water, plants, mines, and also air which is at the bounce of the land concerned). ${ }^{15}$

Article 1338 of the Civil Code states that "all agreements with the law shall apply as laws to those who make them". This agreement shall not be withdrawn except by the agreement of both parties or for the reason prescribed by the Act. The agreement must be well implemented. The provision of the aforementioned article can be argued that in the case of the contract law, the positive law in Indonesia embraces as an open system, its mean that everyone is free to make any contract and anyway is free as long as its permission is in accordance with the public order and or morality. The meaning of "free" sense here is not only concerning the contract or material of the agreement but also concerning how to resolve the dispute that may or may occur.

In line with the coming into the effect of the above principle, Article 10 Paeagraph (1) of Law Number 48 Year 2009 concerning the judicial Authority states that "The court is prohibited from refusing to examine, hear and decide a case filed with the argument that the law is absent or less clear, but obliged to examine and prosecute him". ${ }^{16}$

12 Rahmadi Usman, 2003, Pilihan Penyelesaian Sengeketa di Luar Pengadilan, Citra Aditya Bakti, Bandung hal 1

13 Nurfadilah, Sengketa Tanah Wakaf............hal 75

14 Ihromi, 2001, Antropologi Hukum Sebuah Bunga Rampai, Yayasan Obor Indonesia, Jakarta, hal 210-212

15 Urip Santoro, 2005, Hukum Agraria dan Hak-Hak Atas Tanah, Pranada Media, Jakarta, hal 23

16 Pasal 10 UU Nomor 48 Tahun 2009 tentang Kekuasaan Kehakiman

DOI: $10.9790 / 0837-2303098190 \quad$ www.iosrjournals.org $\quad 86 \mid$ Page


For the settlement of waqf disputes in Law Number 41 Year 2004 stated that there are two paths of dispute settlement of waqf that is through litigation and non-litigation route, or through religious court and Bazarnas. Article 62 Law No. 41 of 2004 on waqf states that: "the settlement of the endowment disputes is pursued through deliberation to reach the consensus, if the dispute settlement referred to in Article 62 Paragraph (1) is unsuccessful, the dispute may be settled through mediation, arbitration or trial.

The way in which non-court settlement disputes result in agreement from the parties involved, are far more able to sustain the ongoing or future relationship than winning-losing procedures as in the litigation dispute process. Court rulings are not problem solving among the disputing parties, but places both sides on two opposite side, placing one party to the winner and concerning the other as the loser. In this position, there are parties who win and lose, then not peace and tranquility that arise, but on the losing side of self-revenge and hatred.

According to Abdul Ghofur in Siska Lis Sulistiani ${ }^{103}$ there are the cause of the land dispute of waqf:

1) Due to the abundance of waqf land which is not followed up by making waqf pledge.

2) Waqf is done on a religious basis based on mutual trust so that it has no legal basis and proof of the ownership.

3) There is no authentic evidence and written document, the clash of religious values with positive economic and legal motivation as well as the rearrangement of territory by the local government.

4) Requested again by the heirs who deviate from the akad waqf contrast

5) Little community knowledge of waqf

6) Consumptive and unproductive use

7) The heir denied the Acting Officer of waqf pledge and the heirs are not informed by their parents so that they sell it even though they already have the deed of pledge of waqf.

As for the party who plays a role in the implementation of waqf law is the Minister of religious Affairs who is obliged to nurture, supervise and involve the waqf Board of Indonesia (BWI), taking into account the suggestions, consideration of the Indonesia Ulama Indonesia (MUI) in fostering and overseeing the implementation of waqf. Then the manager (Nadzir) are tasked with the administering the waqf properties, managing and developing the waqf property ${ }^{17}$ according to the function, supervising and protecting and also reporting their duties to BWI and forbidding to change the utilization of waqf property and waqf's wealth status without permission. Furthermore, the Officer of Deed of Pledge of Waqf is responsible to record the pledge of waqf in accordance with the provision of the Act and examine the completeness of administrative requirements as well as the physical state of the object of waqf.

The Office of Religious Affairs (KUA) has the main duty and the function as mentioned in the decision of the Minister of Religious Affairs of Republic Indonesia Number 18 of 1975 which is carrying out some duties of the Office of the Ministry of Religious Affairs of the District in the field of Islamic Affairs in the area of District. To carry out these tasks, the office of Religious Affairs of the district has the following functions:

a) Conduct the statistics and documentations;

b) Conduct the correspondence, handling letters, archives, typing, and households office of Religious Affairs District;

c) Make the recording of marriage, divorce, reconciliation, take care and build the thing concerned to the mosque, alms, waqf land, baitul mal, social worship, population and build sakinah family, guidance of pilgrimage in accordance with the policy set by the Ministry of Religious Affairs and applicable legislation.

The role of the Office of the sub-district Religious Affairs is very important in solving all religious law matters, especially in the case of law in resolving the dispute of waqf land in the community. If the land dispute of waqf cannot be resolved by the customary law, then the office of religious affairs is expected to be able to bridge to settle the Islamic law.

Indeed, the practice of land waqf in Gorontalo Province has not been implemented properly as one of the examples of cases that have occurred. In this case it is mentioned that someone has donated the land for schools and mosques. In its development, along with the increasing population growth, the land which they are represented was event used with the other interests. After the landowner, his son, who manages the land, acknowledges that the land which has been used as a school and mosque is not the land is not the represented land, but the land of his father's inheritance. Its proof of the ownership is indicated by the manager (Nadzir) through Letter C. Based on the results of the Districts Court Examination, the verdict states that the land for schools and mosques are waqf land that serves as schools and mosques. The district court ordered the managers (Nadzir) to register the waqf land to the Office of Religious Affairs of the sub district as the pledge officer of waqf deed (PAIW).

17 Siska Lis Sulistiani, 2017, Pembaharuan Hukum Wakaf di Indonesia, Refika Aditama, Bandung, hal 151

DOI: 10.9790/0837-2303098190 $\quad$ www.iosrjournals.org $87 \mid$ Page


Another case that occurred was the case of a mosque building in one of the village sealed by local residents because allegedly still in dispute because the process of waqf land is not yet complete and still handled by the court.

Based on the above mentioned cases, viewed from the perspective of conflict resolution theory by Ralf Dahrendorf in Saifudin Noorhadi ${ }^{18}$ that the occurrence of conflicts caused by several factors as follows:

First, the problem of resources; land is one of the unrenewable natural resources and one of the most vital capital for all production activities, either a rural farms and the strategic land in urban areas. Therefore, the land occupies an important position in everyday life and has a multidimensional meaning for the society. In relation to that, the use of consumptive and productive land which has not been productively utilized and the scarcity and limitation of land compared to the population, causing the heir to waqif irregularities and allegations against the land that has been represented, either by selling or by requesting the compensation amount of the money to managers (Nadzir).

Many factors encourages a person not to recognize the existence of a pledge of waqf or to withdraw the property that has been represented, either by the self-condemned or by the heirs. Among other things, the increasing scarcity of land, the higher prices, the depletion of religious consciousness, and may also be caused by people who endow has represented all of his property so that the offspring feel lost sources of the sustenance and become displaced. Waqf practice that do not take into account the source of the sustenance for their descendants of the responsibility can be a disaster and catastrophe for the abandoned generation. Therefore, there are also the heirs who deny the existence of waqf pledges from their parents, do not want to hand over the waqf land to the designated nadzir or to all do not want to inform the officers of the pledges of waqf that he heard from his parents.

Second, the issue of interest or needs. One of the waqf land dispute mentioned above is due to a conflict of the interest between the developers to build the settlements in order to meet the needs of the board for the community with the interest to continue to prserve and to perpetuate the purpose function, and the designation of waqf land as schools and mosques. There is also a dispute of waqf land caused by a conflict of the interest between the heirs who feel entitled to the land that has been represented with the nadzir party which designates the waqf land as a place of worship or Mushala.

The population growth, especially in the city, prompted the government to rearrange the spatial planning in accordance with the needs of the community. The development for the public interest as written in Presidential Decree Number 36 Year 2005 on Land Procurement for the Implementation of the Development and confirmed in Law No. 2 of 2012 on Land Procurement for the Development for Public Interest. Often associated with the insistence of exchange, sale, and transfer of waqf land. This is in accordance with the benefits which must be opened the corridor that is related to the responsibility of the manager (Nadzir) although in a very strict way in a positive law that must arranged.

The legislation permits the changes to the endowments provided for in Article 11 of Government Regulation Number 28 of 1977 on the Ownership of Endowments and Article 41 Year 2004 regarding waqf. In the past, the changes in the status of the land represented can be done by the manager (Nadzir) with any convincing reason. Such a thing would certainly cause a reaction from the public, especially from those who directly concerned with the representation of the land. In the legislation, strict restictions are imposed with a prior approval from the Minister of Religious affairs. In this way, it is hoped that the avoidance of harmful practices will be avoided. For the purpose of land administration, the changes in the status of waqf must be registered with the component authority.

Third, the problems of values (religious values, culture, morals, etc.). One of the causal factors of waqf land dispute basically started from the action of the heirs which sold the part of the represented land by his parents, even though the waqf land has the Deed Waqf (AIW). In this case there a clash of religious values to keep using and utilizing the waqf land in accordance with its function and appropriation with the economic motivation of the heirs because the value exchange of the land is higher and higher. While the other causative factor is the absence of the authentic evidence related to waqf land, so that the heir or waqif feels entitled to the land. In this case, the cause of the dispute is a clash between the religious values that the waqf is legally valid if it has fulfilled the conditions determined by the religion even though it is not registered or there is no waqf pledge deed with the positive legal value ordering and mandating that the waqf land is registered as affirmed in Articles 9 and 10 of Government Regulation Number 28 year 1977; as well as in Articles 32-39 of Law number 41 of 2004 about waqf. In addition, the dispute is also caused by the clash of religious values and economic motivation of the heir or waqif.

18 Saifudin Noorhadi, 2005, Wakaf Dalam Perspektif Hukum Agraria Nasional; Kajian teoritik ke arah pengelolaan dan pendayagunaan tanah wakaf bersifat produktif-komersial (Disertasi) PPS Brawijaya Malang hal 37 
Fourth, the familial relationship between the waqif and the heirs that has triggered the assumption of the heirs that the land which has been represented is the inherited land of his parents, so that the heir waqif feel entitled to sell the land to the other parties. There is also a waqf land dispute which begins from the demands if compensation on the waqf land of the heir waqif because they assume that the waqf land is inherited from his parents. Whereas since ten of years on the land stands the mosque or public facilities such as schools which has been used and utilized by the surrounding community.

Such conditions are triggered by the lack of knowledge about waqf, both according to the Islamic law and legislation, resulting in the perception of the community that waqf is worship so that it is not necessary anymore if waqf is known to other by written even to be with the deed. There is still a way of thinking or the assumption that without any certificate, the legal status of waqf land is strong enough because for decades even more the land is used and utilized in accordance and designated of waqf, no claims or demands from any party, so the assumption is encouraging the deviation from the nature of law and the purpose of waqf so that there is a dispute land waqf.

The communities in carrying out the waqf still use the religious habits, such as the habit of performing legal acts of representation orally on the basis of mutuakl ltrust to a person or a particular institution, the custom of viewing waqf as a pious deed which ha a noble value in Allah's side without having to go through the administrative procedures and waqf property his considered belonging to God alone and anyone will not dare to disturb the law without permission of Allah. The high trust to the recipient mandate in doing the waqf without a written evidence can invite a dispute in the future.

Fifth, the problem structure. The different views and the perceptions between community and government related to the implementation of waqf can lead to conflicts that lead to dispute. Since the arrival of Islam, waqf has been implemented based on the understanding held by the most of the Islamic community in Indonesia, namely shafi'iyah and local customs. In this case, the Act of condoning the land is done verbally without ant written evidence on the basis of trust. Whereas in legislation, it is affirmed that waqf must be done in accordance with the administrative representation, the procedure of granting the rights, and the procedure to get the certainty of the land right which is represented, where the provision is unknown and not previously known by the society. The existence of waqf land which does not meet the administrative requirements as defined in the laws and regulations causes inequality and imbalance in terms of legal certainty, when compared with the land of waqf that has a certificate. The absence of the authentic evidence and written documents relating to waqf land is not sufficiently robust in jurisdiction because there is no legal certainty on waqf land in case of claims from the interested parties.

The description, if related to Law Number 41 year 2004 regarding waqf, then there are some potential violations of law that can occur, namely:

1) If not carried out the obligations in terms of the structural waqf. The waqf structures include the Government (Ministry of Religious Affairs), Waqif, NAdzir, Acting officer of Pledges of Waqf, Islamic Financial Institutions and Indonesia Waqf Board).

2) If it is not accordance with the implementation of the obligation of the waqf structures as stipulated in the legislation

3) The waqf structure violates the rules which set out the law. The violatuons committed structurally by the Ministry of Religious Affairs which have been stated in Article 63 of the Law on waqf, they are:

1. The ministry of Religious Affairs does not conduct the guidance and supervision on the implementation of waqf to realize the purpose and the function of waqf.

2. Especially with regard to guidance as referred to in paragraph (1), the Ministry of Religious Affairs shall not include the Indonesian waqf board.

3. The guidance and supervision as referred to in Paragraph (1) and Paragraph (2) shall be done without considering the advice and the consideration of the Indonesian Ulama Indonesia (MUI). If the Ministry of Religious Affairs does not carry out the process mandated by the law, the Ministry of Religious Affairs may be categorized as having committed a violation of the responsibilities.

The potential for further violations are those committed by the management (Nadzir) as stated in Article

11 of Law Number 41 year 2004 regarding the waqf that badzir does not perform ,the following tasks:

a. Administering the waqf property

b. Managing and developing the waqf property in accordance with the purpose, function, and designation,

c. Overseeing and protecting the waqf property

d. Reporting the implementation of the duties to Indonesian Waqf board

e. Managing and developing the waqf property. Nadzir is prohibited from altering the use of waqf property except on the basis of written permission and the Indonesian Waqf Board

f. The permit as referred to in Paragraph (1) may only be granted if the waqf property cannot be used in accordance with its designation stated in the pledge of waqf. 
The potential for further violations shall be made slightly by the official of Deed of Pledge of waqf deed which stated in Article 21 paragraph (1) and (2), namely:

1) Waqf pledge is poured in the Deed of Pledge of waqf

2) The deed of waqf pledge as referred to in Paragraph (1) shall at least contain: a. waqif name and identity; b. Badzir's name and identity; c. data and description of waqf property; d. designation of waqf property; e. the duration of waqf.

If the pledge officer of waqf deed pledge does not pour the pledge of waqf in the deed of pledge of waqf, has made the deed of waqf allegiance but does not contain the matter set out in law.

\section{CONCLUSIONS}

Based on the problem and discussion of the research, it can be concluded that the nature of waqf land is to get closer to Allah SWT, which contain the meaning of charity actions continuously useful to the entire community. However, in its implementation practice the waqf land is less effective because the waqf land mostly do not have the deed of waqf pledge so it is rather difficult to be registered at the National Land Agency for the manufacture of the certificate. The substance of the land law for the effectiveness of waqf practice has not been well implemented because there are still many uncertified land of waqf.

\section{REFERENCES}

[1] Abdurahman, 1984, Masalah Perwakafan Tanah Milik dan Kedudukan Tanah Wakaf di Negara Kita, Alumni, Bandung.

[2] Ahmad K. and Djanggih H. (2017). Batasan Penerapan Asas Persidangan Terbuka untuk Umum dalam Siaran Persidangan Pidana oleh Media. Jurnal Ius Quia Iustum, 24 (3), 488505.DOI.10.20885/iustum.vol24.iss3.art8. http://journal.uii.ac.id/IUSTUM/article/view/8644/8095.

[3] Chidir Ali, 1979, Yurispondensi Indonesia Tentang Hukum Agraria Jilid 1, Binacipta, Bandung .

[4] Djanggih, H., \& Ahmad, K. (2017). The Effectiveness of Indonesian National Police Function on Banggai Regency Police Investigation (Investigation Case Study Year 2008-2016). Jurnal Dinamika Hukum, 17(2), 152-157. DOI: 10.20884/1.jdh.2017.17.2.722

[5] Djanggih, H., \& Salle, S. (2017). Aspek Hukum Pengadaan Tanah bagi Pelaksanaan Pembangunan untuk Kepentingan Umum. Pandecta: Research Law Journal, 12(2), 165-172. DOI: http://dx.doi.org/10.15294/pandecta.v12i2.11677

[6] Ihromi, 2001, Antropologi Hukum Sebuah Bunga Rampai, Yayasan Obor Indonesia, Jakarta

[7] Muhsin, 2004, Ikhtisar Sejarah Hukum, STIH IBLAM, Jakarta.

[8] Rahmadi Usman, 2003, Pilihan Penyelesaian Sengeketa di Luar Pengadilan, Citra Aditya Bakti, Bandung.

[9] Saifudin Noorhadi, 2005, Wakaf Dalam Perspektif Hukum Agraria Nasional; Kajian teoritik ke arah pengelolaan dan pendayagunaan tanah wakaf bersifat produktif-komersial (Disertasi) PPS Brawijaya Malang.

[10] Saroso dan Nico Ngani, 1984, Tinjauan Yuridis Tentang Perwakafan Tanah Milik, Liberty, Yogyakarta.

[11] Siska Lis Sulistiani, 2017, Pembaharuan Hukum Wakaf di Indonesia, Refika Aditama, Bandung

[12] Taufik Hamami, 2003, Perwakafan Tanah dalam Politik Hukum Agraria, Tata Nusa, Jakarta

[13] Ter Haar, 2001, Asas-asas dan Susunan Hukum Adat, Penebar Swadaya, Jakarta.

[14] Urip Santoro, 2005, Hukum Agraria dan Hak-Hak Atas Tanah, Pranada Media, Jakarta.

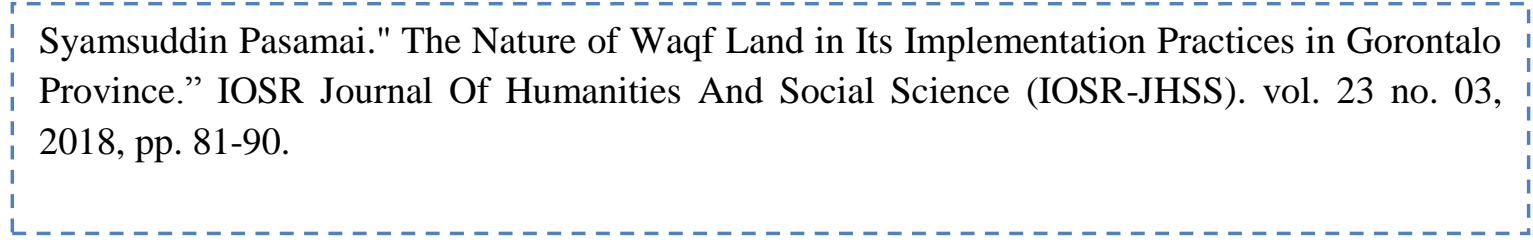

